\title{
16. PETROGRAPHY AND GEOCHEMISTRY OF PYRITE AND MARCASITE IN DSDP LEG 40 SEDIMENTS
}

\author{
William G. Siesser, Department of Geology, University of Cape Town, Rondebosch, South Africa
}

\section{INTRODUCTION}

Authigenic iron sulfide, normally reported as pyrite, is a ubiquitous component of deep-sea sediments. Leg 40 sediments are no exception; iron sulfide occurs throughout the cores. Pyrite also occurs in onshore sedimentary sequences. Love and Amstutz (1966) cite more than 100 papers describing the widespread geographic and stratigraphic occurrence of this mineral.

Interest in Leg 40 iron sulfides was heightened by the shipboard suspicion, later confirmed, that some grains were marcasite rather than pyrite. Marcasite has rarely been reported in other DSDP cores. Either it is seldom present at other sites, or has not been distinguished from pyrite. It is difficult to distinguish between pyrite and marcasite in smear slides, and X-ray diffraction may not detect small amounts of marcasite. The relatively good crystal forms of the Leg 40 grains, first recognized in the coarse sediment fraction, initially suggested that some grains were marcasite.

The purpose of this reconnaissance study is (1) to describe the occurrence of pyrite and marcasite, in particular noting the different morphological forms the minerals assume, and the relative abundance of each, (2) to contrast the major and some minor element contents of grains in different morphological classes, as well as from different drilling sites, and (3) to document the unusual association of pyrite and gypsum found in some of the cores.

\section{PETROGRAPHY}

Fifty-eight samples known or suspected to contain iron sulfides were wet-sieved to separate the $>177 \mu \mathrm{m}$, $177-89 \mu \mathrm{m}$, and $<89 \mu \mathrm{m}$ size fractions. Fifty-three of the samples contained iron sulfides. Site 364 was more throughly investigated than the other sites, since both marcasite and native copper (Siesser, this volume) were found there. Representative grains were picked from the two coarse fractions of the samples that contained iron sulfides and the relative abundances of various morphological types were estimated (Table 1). The morphologies represented are classified as follows:

\section{Pyrite}

1) Cubes-grains are single cubes or aggregates (Figures 1 and 2) of cubes or, less commonly, octahedra. Crystal forms are occasionally striated.

2) Framboids-spheroidal grains composed of octahedral or pyritohedral forms (Figure 3). Crystal faces are sometimes heavily etched (Figure 4).
3) "Worm" tubes-straight or slightly curved tubes. The surfaces may be finely granular (Figure 5) or knobby (Figure 6).

4) Irregular masses-these grains have granular (Figure 7) or microplaner (Figure 8) surfaces. This is the most common morphological type.

5) Botryoidal-sub-spherical aggregates (Figure 9 and 10). Both pyrite and marcasite may take this morphological form; these grains could as easily be marcasite, but are assigned to pyrite because of their minor element content (see Geochemistry section).

6) Fossil casts-infillings of fossil chambers (Figure 11), mostly of foraminifer and molluscs.

7) "Nodules" of pyrite (i.e., pebble size or greater) are also noted on Table 1.

\section{Marcasite}

1) Radiating clusters-made up of mostly tabular, but some pyramidal crystals radiating from a common center. The tabular crystals often show characteristic "spearhead" twins (Figures 12 and 13). Tarnish colors are more common in this and the next (pyramidal) groups than in the pyrite groups.

2) Pyramidal-single or clusters of pyramidal forms oriented irregularly to one another (Figures 14 and 15).

\section{GEOCHEMISTRY}

Electron-microprobe analysis for $\mathrm{K}, \mathrm{Si}, \mathrm{Ca}, \mathrm{Al}, \mathrm{Ti}$, $\mathrm{Mg}, \mathrm{Fe}, \mathrm{Mn}, \mathrm{S}, \mathrm{Cu}$, and As were performed on 19 selected grains of pyrite and marcasite. Results are presented in Table 2.

Small amounts of $\mathrm{K}, \mathrm{Si}, \mathrm{Al}, \mathrm{Ti}$, and $\mathrm{Mg}$ were detected. However, it is possible that these elements may not be chemically bound in the iron sulfide compounds. Although analysis sites on an iron sulfide grain were carefully selected, and appeaed to be uncontaminated, these elements could be contained in minute particles of insoluble clay or other impurities physically incorporated within the sulfide grains during their growth. Clay and calcium carbonate are commonly seen within small internal cavities in the larger pyrite nodules.

Manganese, on the other hand, shows a definite and selective affinity for marcasite grains. The analyzed marcasite grains averaged about $1.1 \% \mathrm{Mn}$; the pyrite grains averaged less than $0.1 \% \mathrm{Mn}$. The low $\mathrm{Mn}$ content $(0.07 \%)$ of the botryoidal group was the reason for eventually assigning these grains to pyrite, rather than marcasite, in the absence of conclusive crystallographic evidence. Marcasite grains also appear to contain relatively less $\mathrm{Fe}$ than pyrite (Table 2 ), but not enough grains were analyzed to confirm this observation. 
TABLE 1

Relative Abundances of Pyrite, Marcasite, and Gypsum in Leg 40 Sediments

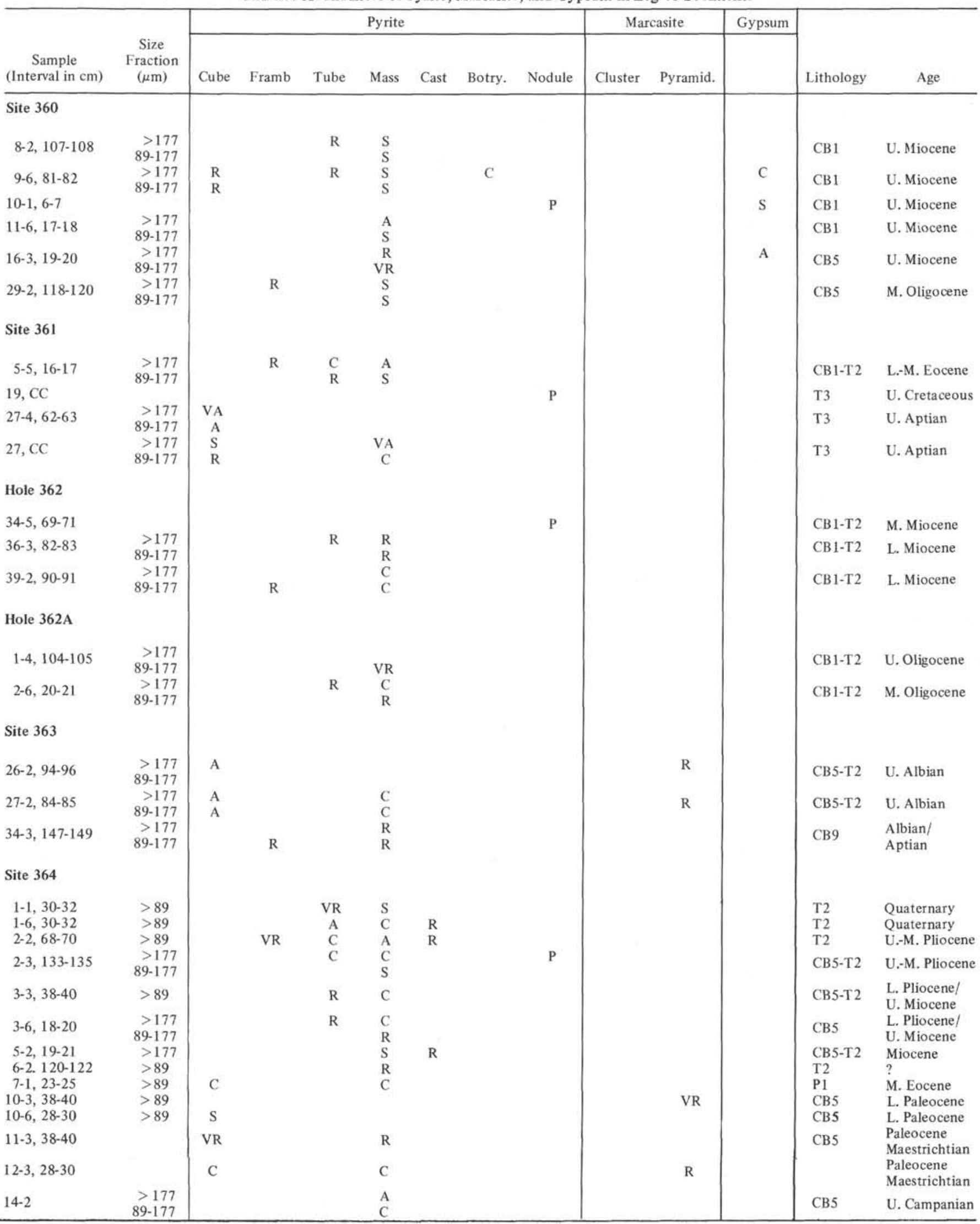


TABLE 1 - Continued

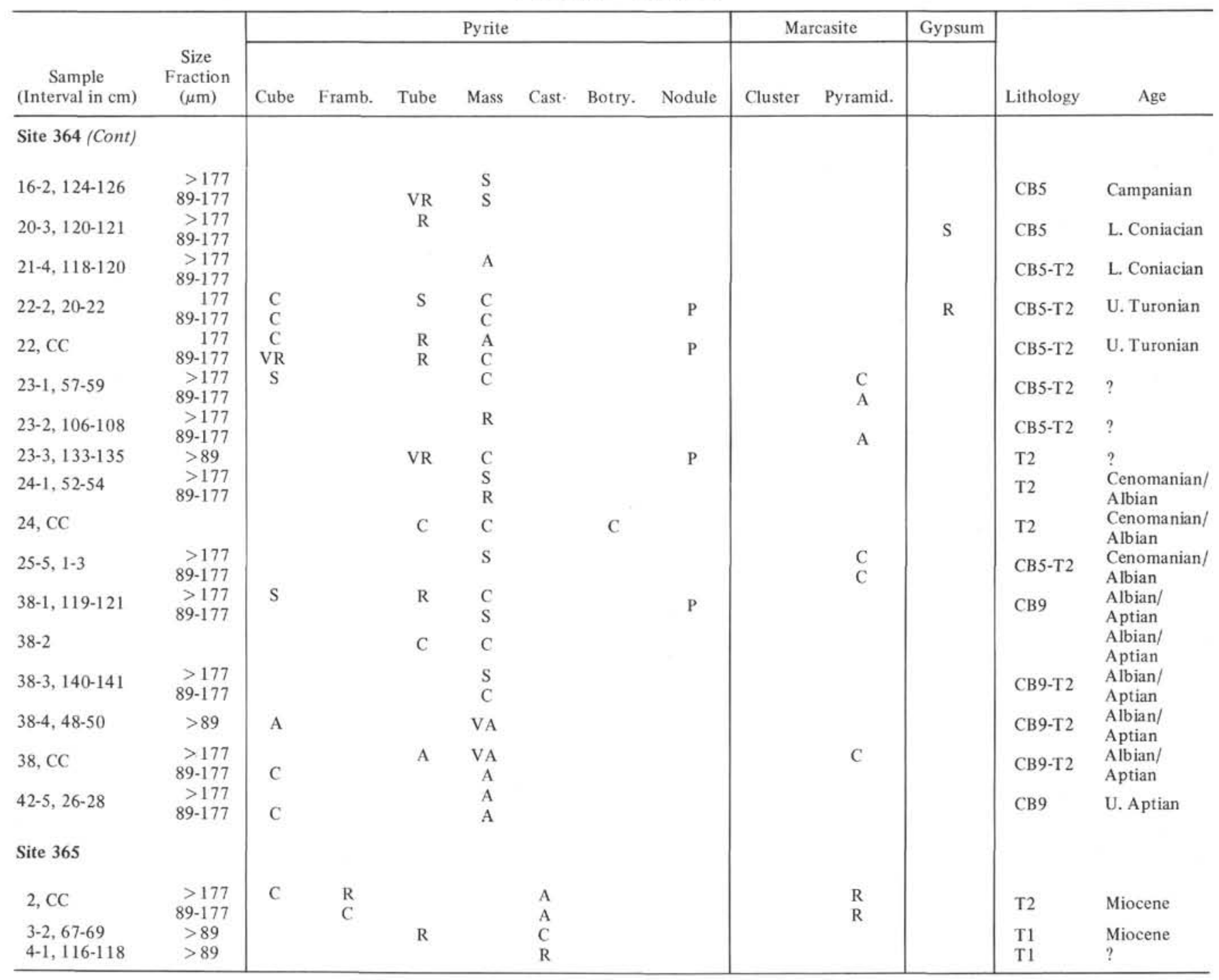

Note: $\mathrm{VA}=$ very abundant, $\mathrm{A}=$ abundant, $\mathrm{C}=$ common, $\mathrm{S}=$ sparse, $\mathrm{R}=$ rare, $\mathrm{VR}=$ very rare, $\mathrm{P}=$ present.

However, it is interesting to note that Edwards and Baker (1951) reported a similar low $\mathrm{Fe}$ content in marcasite relative to pyrite.

\section{ORIGIN}

Pyrite has long been known to be associated with anaerobic or partly anaerobic sulfide environments, i.e., environments deficient in oxygen but rich in $\mathrm{H}_{2} \mathrm{~S}$. Anaerobic conditions normally occur when there is an abundance of organic matter deposited on the sea floor. Decomposition of the organic matter removes available oxygen creating an anaerobic environment of variable thickness in the bottom layer of seawater, and/or below the sediment-water interface. Anaerobic bacteria reduce dissolved sulfate, consuming the oxygen by metabolism. The sulfur that they liberate combines with hydrogen from the water to form $\mathrm{H}_{2} \mathrm{~S}$.

Berner $(1969,1970)$ has made a thorough analysis of the source of sulfur and other conditions necessary to form pyrite. He concluded that the two principal sources for sulfur are (1) bacterial reduction of dissolved sulfate, and (2) decomposition of organic matter containing sulfur compounds. However, calculations show that organic matter alone could not provide enough sulfur for the observed pyrite content in sediments, thus supporting a continuous diffusion of sulfate into sediments from the overlying seawater. Nonbacterial sulfate reduction does not occur. Moreover, the bacteria need a sufficient amount of metabolizable organic matter to use as an energy source in their process of reducing sulfate to sulfide. Available organic matter is thus a limiting factor in the amount of pyrite that can be produced.

Dissolved $\mathrm{H}_{2} \mathrm{~S}$ reacts immediately with reactive forms of iron present, which are derived from clastic iron minerals (Berner, 1964) and clay minerals (Carroll, 1958). Increases in pyrite concentration result from increasing iron content and reactivity. Initially, the iron compounds produced are black, finely disseminated 


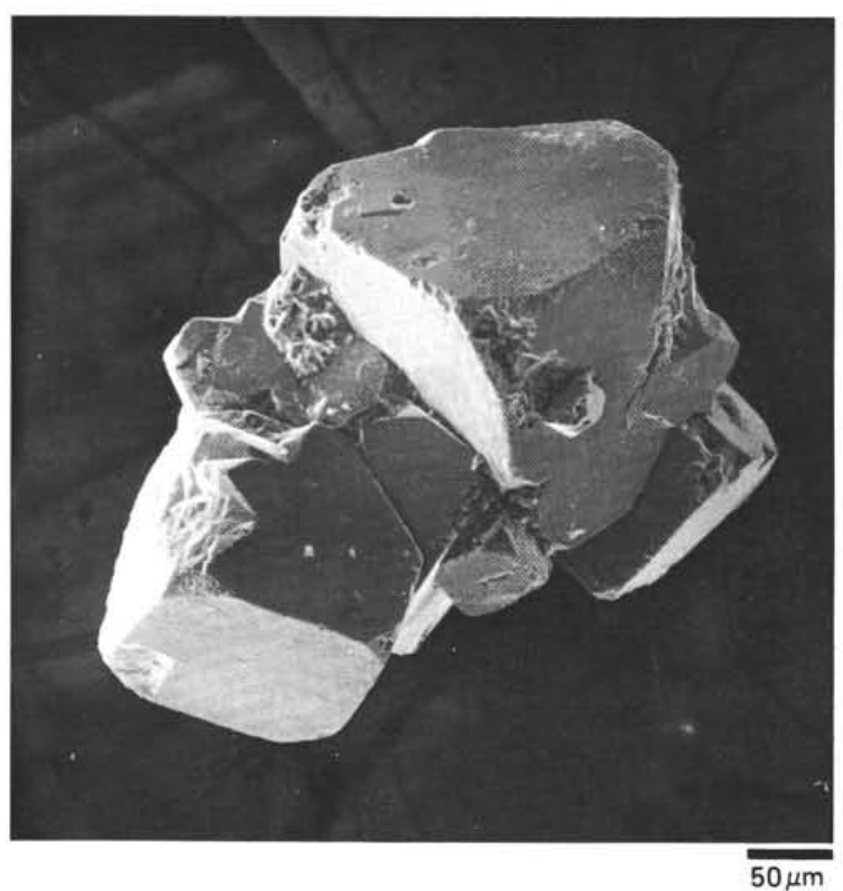

Figure 1. Aggregates of pyrite cubes. Section 361-27-4.

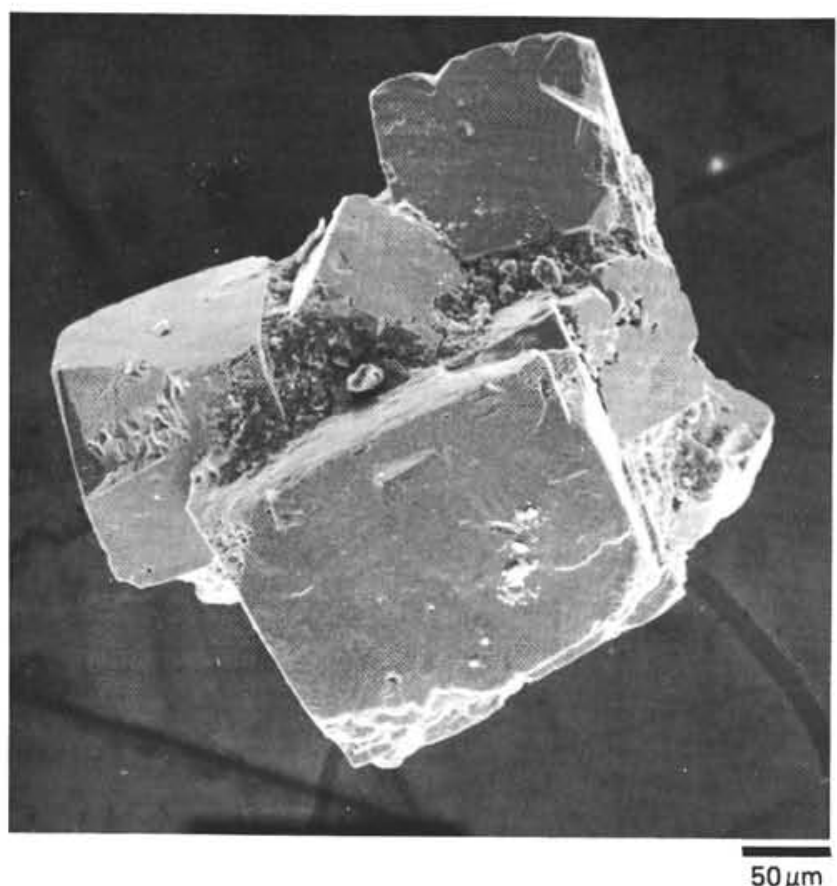

Figure 2. Aggregates of pyrite cubes. Section 361-27-4.

iron monosulfides $(\mathrm{FeS})$ such as mackinawite, greigite, pyrrhotite, or "hydrotroilite."

Further transformation of a monosulfide to the disulfide (pyrite) requires the addition of sulfur, rather than the removal of iron. This reaction requires the presence of elemental sulfur, which slowly reacts with $\mathrm{FeS}$ to form $\mathrm{FeS}_{2}$. Elemental sulfur is produced by the oxidation of $\mathrm{H}_{2} \mathrm{~S}$, either (1) inorganically, utilizing dissolved oxygen, or (2) by sulfur-oxidizing (aerobic) bacteria. Berner maintains that most sedimentary

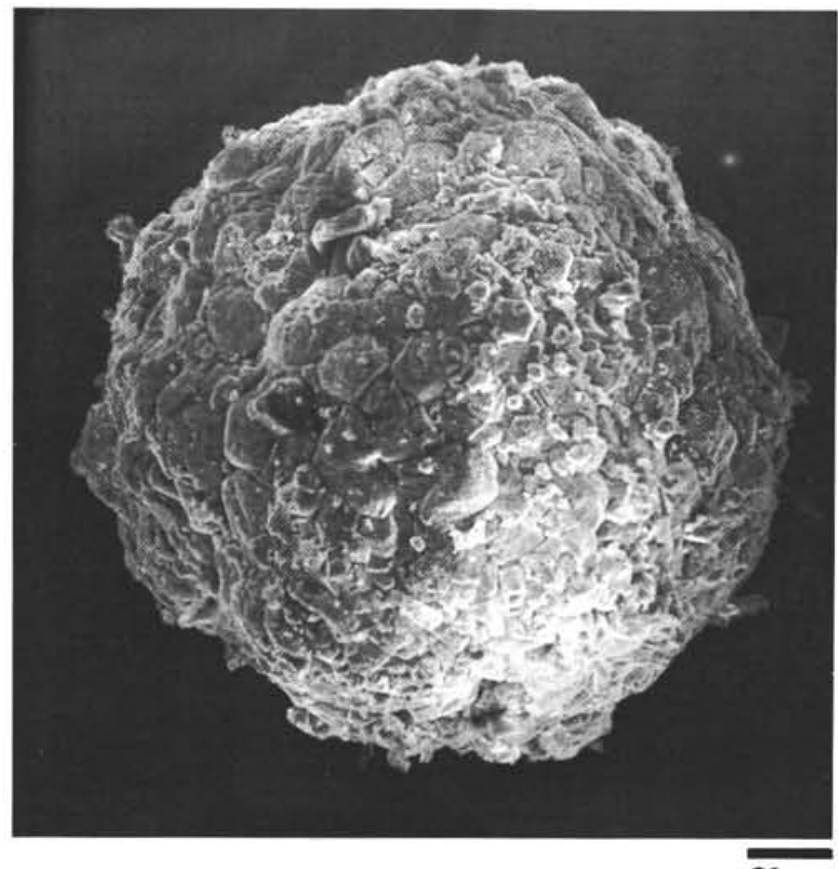

$50 \mu \mathrm{m}$

Figure 3. Pyrite framboid. Section 361-5-5.

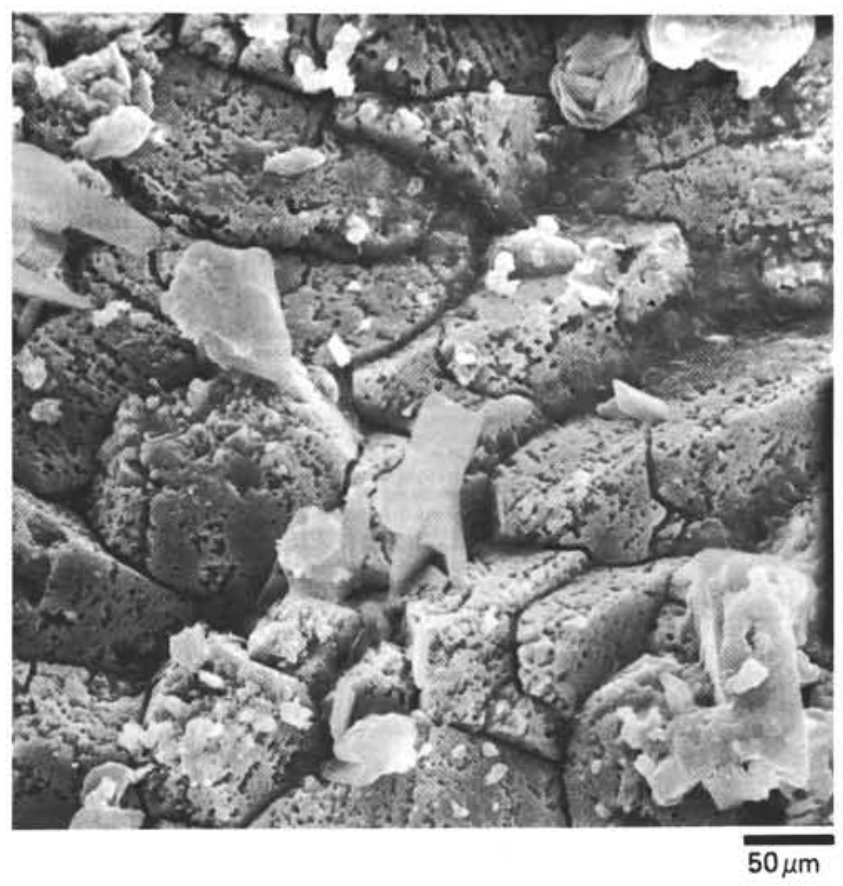

Figure 4. Close-up of Figure 3 showing etching on crystal facies. White flakes are clay particles.

pyrite formation takes place beneath partly aerobic water. Oxygen may then be periodically introduced into the sediments by storm and current agitation or by burrowing organisms. The production of elemental sulfur in sediments overlain by aerobic waters can thus be accounted for. Production under anaerobic waters, however, must occur by a yet unknown process.

Pyrite in Leg 40 samples formed in extremely anaerobic sediments, such as the Lower Cretaceous 


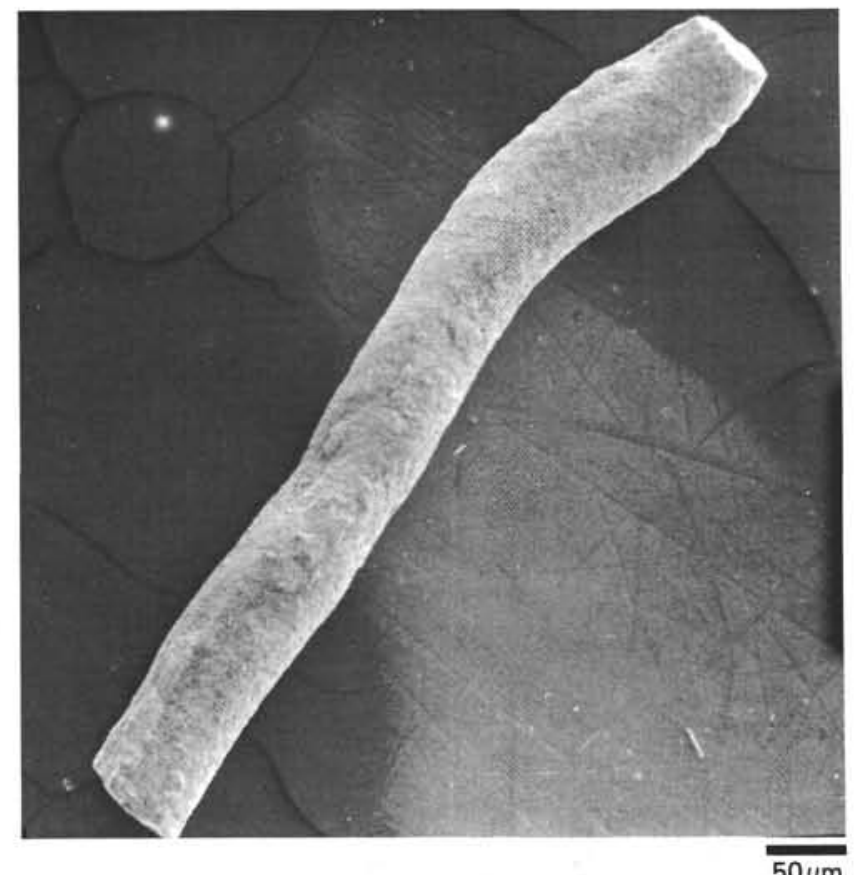

Figure 5. Finely granular "worm" tube of pyrite. Section $362 A-2-3$

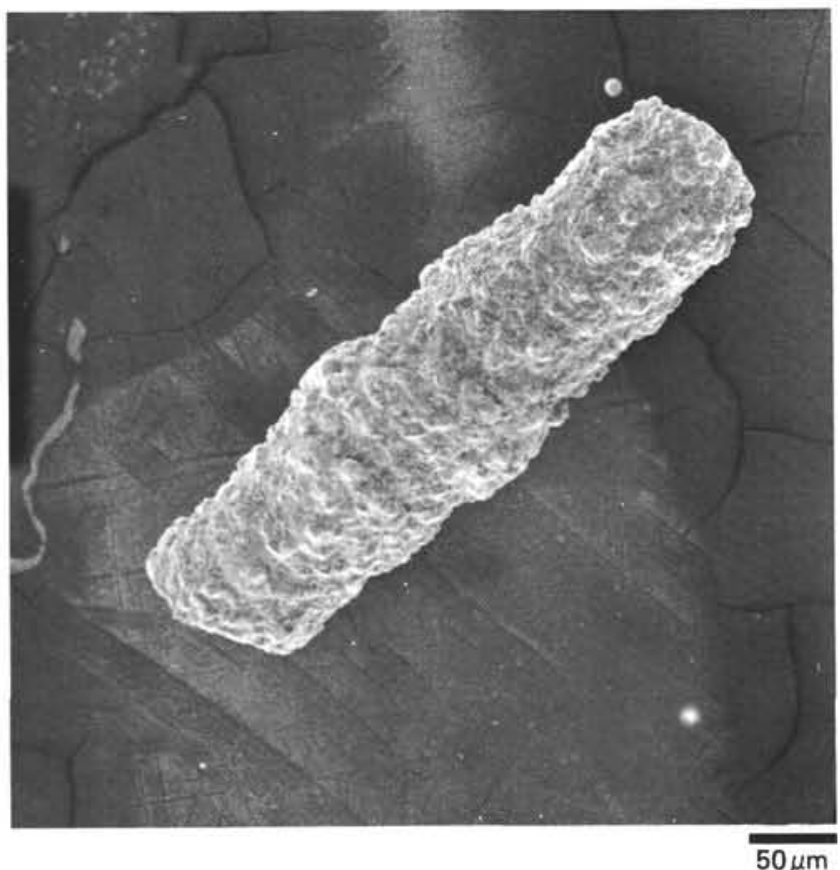

Figure 6. Pyrite "worm" tube with a knobby surface. Section 364-2-3.

sequence at Site 361, and in apparently normally oxygenated open-ocean sediments, as for example at Site 360 . Nevertheless, even the "normal" bottom sites must have been locally depleted in oxygen in order for anaerobic bacteria to initiate the sulfate-reduction process.

An unusual association of pyrite and gypsum was noted in some samples, notably at Sites 360 and 364

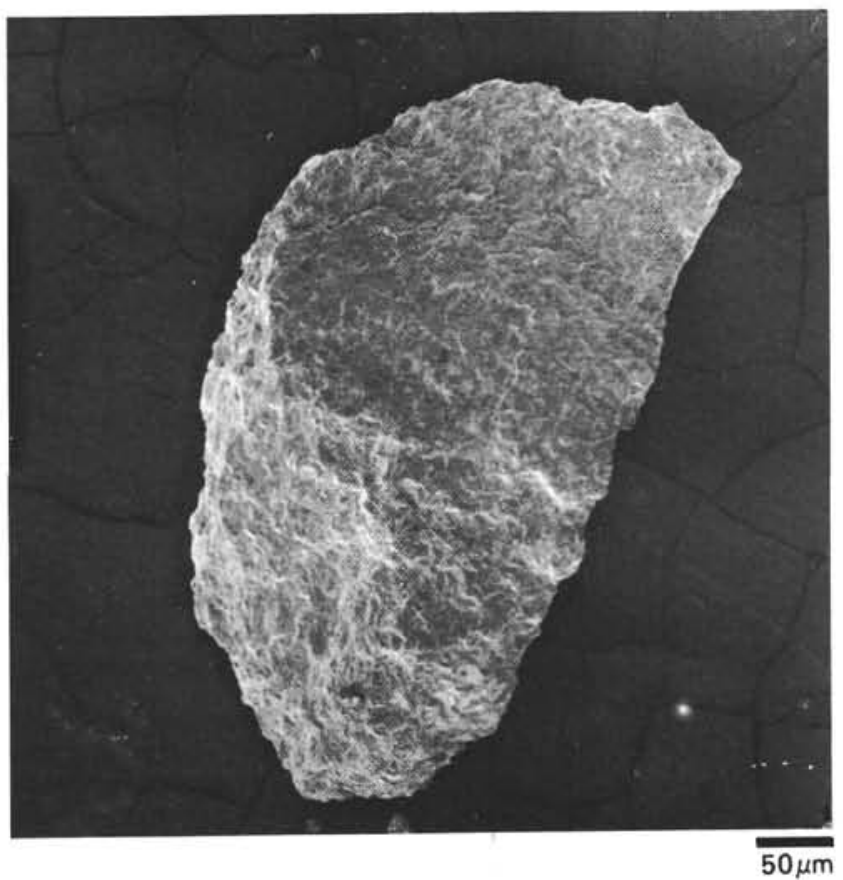

Figure 7. Irregular mass of pyrite with a granular surface. Section 364-21-4.

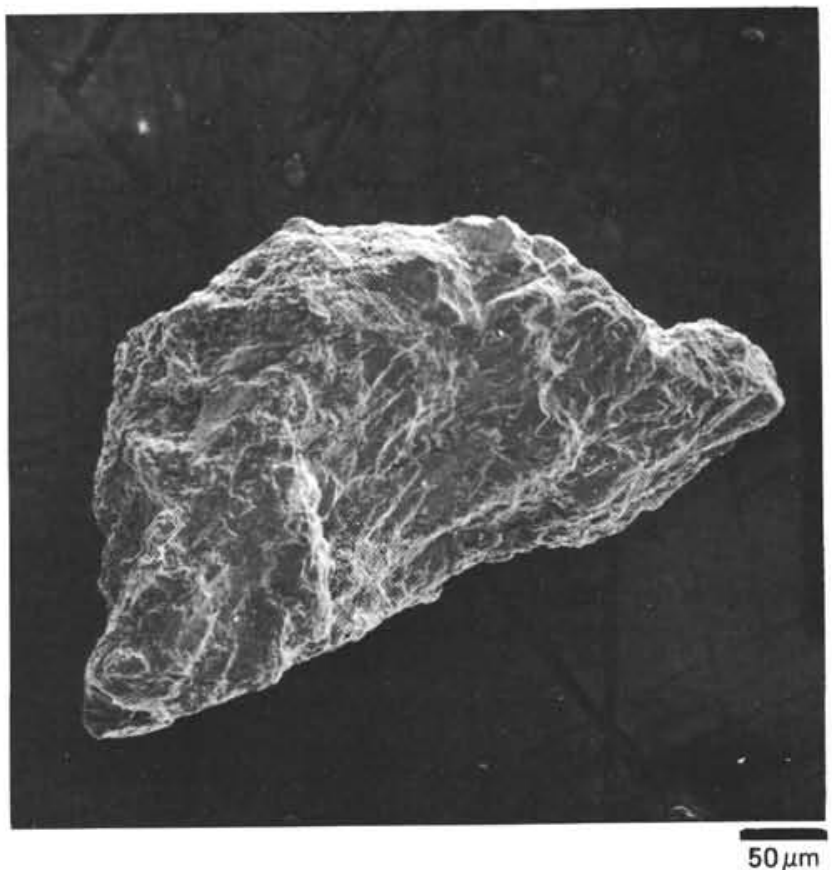

Figure 8. Irregular mass of pyrite with a microplaner surface. Section 364-22 CC.

(Table 2). This association is "unusual" in the sense that one mineral is a sulfide and the other a sulfate. Criddle (1974) was the only previous writer to note the association of these minerals in DSDP cores. Criddle (1974) made the logical and correct assumption that "gypsum was formed by the reduction of sulfate ions introduced during the pyrite formation, with calcium carbonate from the sediment." 


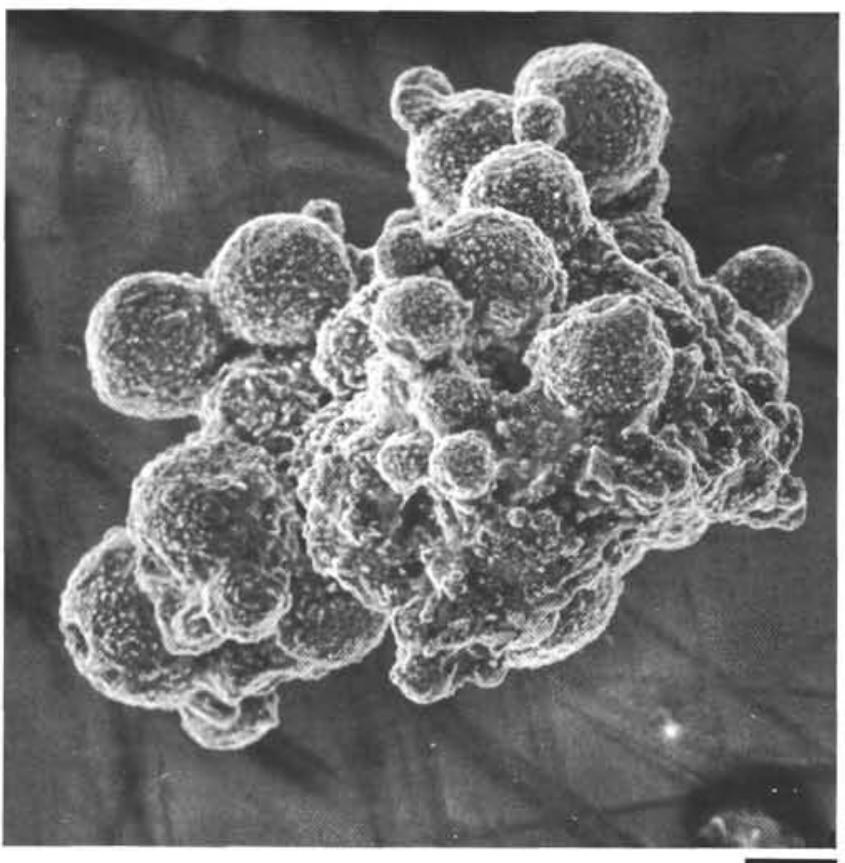

$50 \mu \mathrm{m}$

Figure 9. Botryoidal aggregate of pyrite. Section 364-24 $C C$.

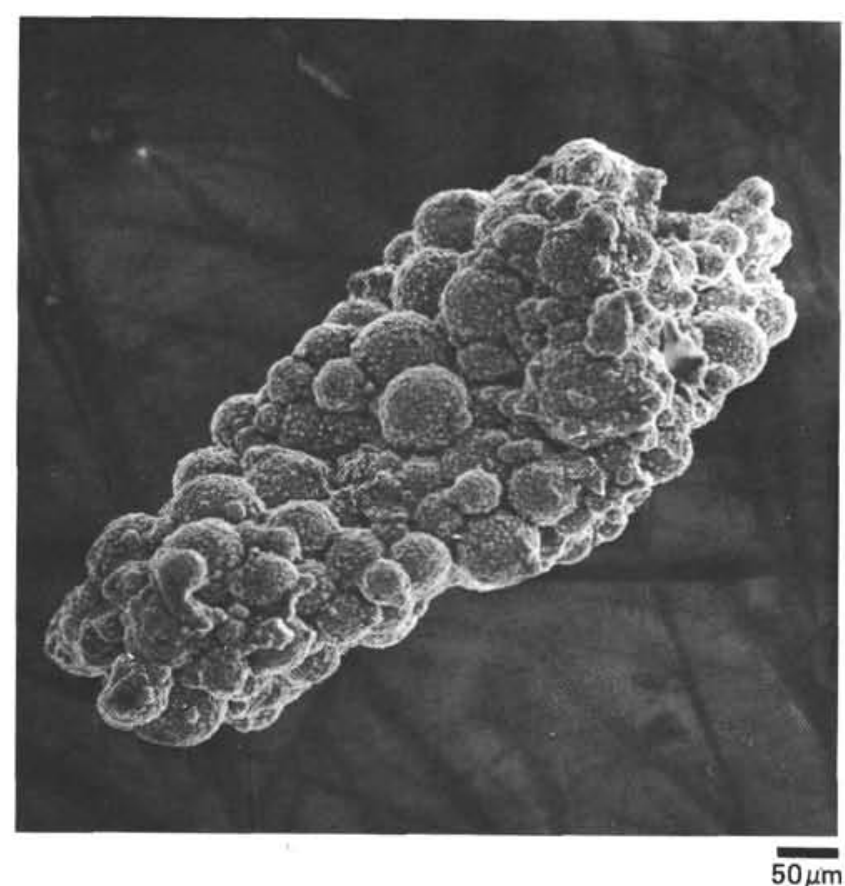

Figure 10. Botryoidal aggregate of pyrite. Section 364-24 $C C$.

Siesser and Rogers (1976) have reported an association of authigenic pyrite and gypsum in southwest African continental-slope sediments. They invoke upwelling of nutrient-rich waters along this coast as the first step in establishing anaerobic zones, conducive to pyrite formation, in places on the continental slope. The anaerobic muds had a sufficiently low $\mathrm{pH}$ to dissolve the skeletons of calcareous organisms and liberate calcium. Sulfate was continuously introduced

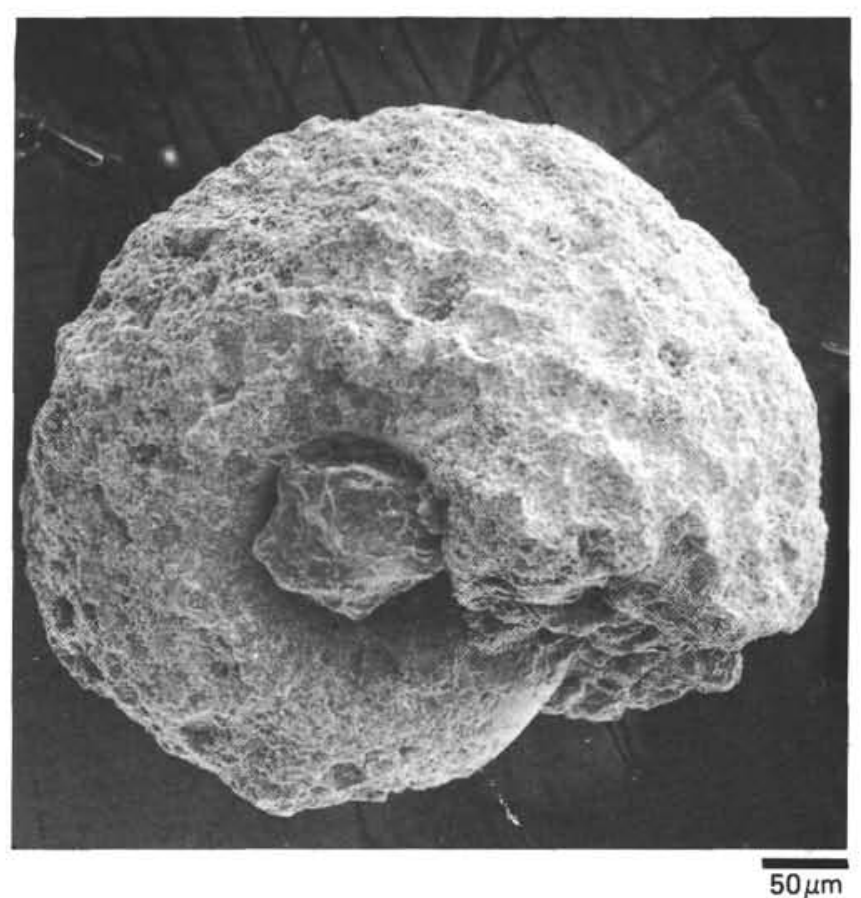

Figure 11. Pyrite cast of a fossil; probably a micromollusc. Section 361-5-5.

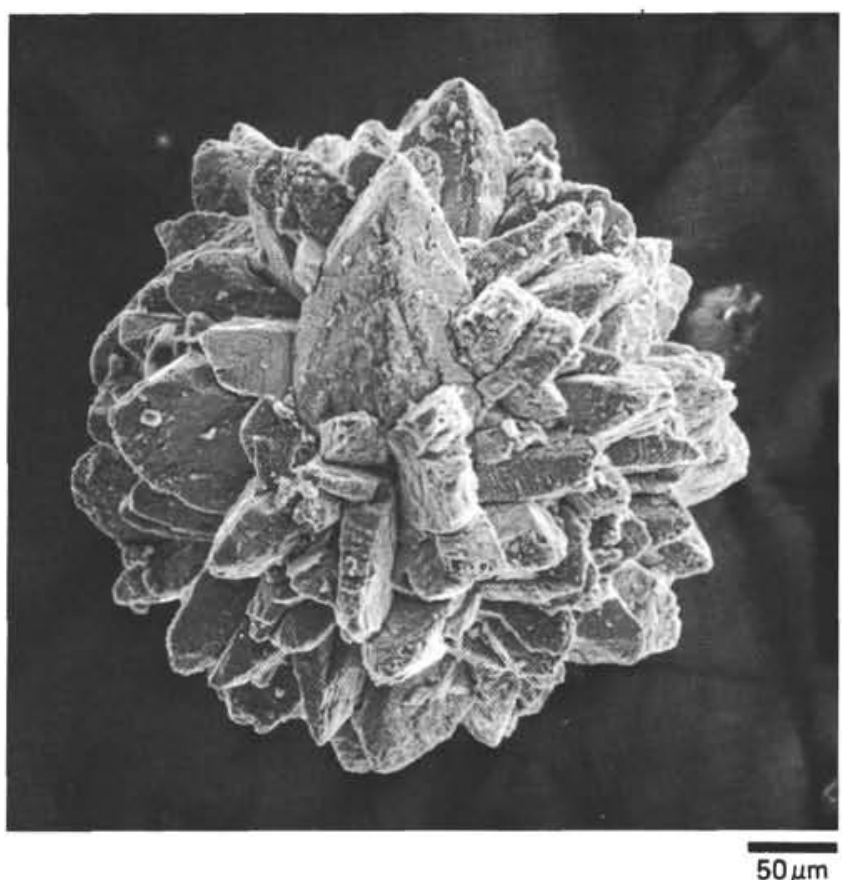

Figure 12. Radiating cluster of marcasite. Note the "spearhead twins. "Section 364-38-2.

into the sediments from the overlying seawater. Gypsum was precipitated once the product of the concentrations of calcium and sulfate ions exceeded the gypsum solubility product. Gypsum crystals often enveloped the earlier formed grains of pyrite (Siesser and Rogers, 1976)

A similar process must have formed the Leg 40 gypsum grains. Localized low-pH environments dissolved calcium carbonate, thus releasing excess 


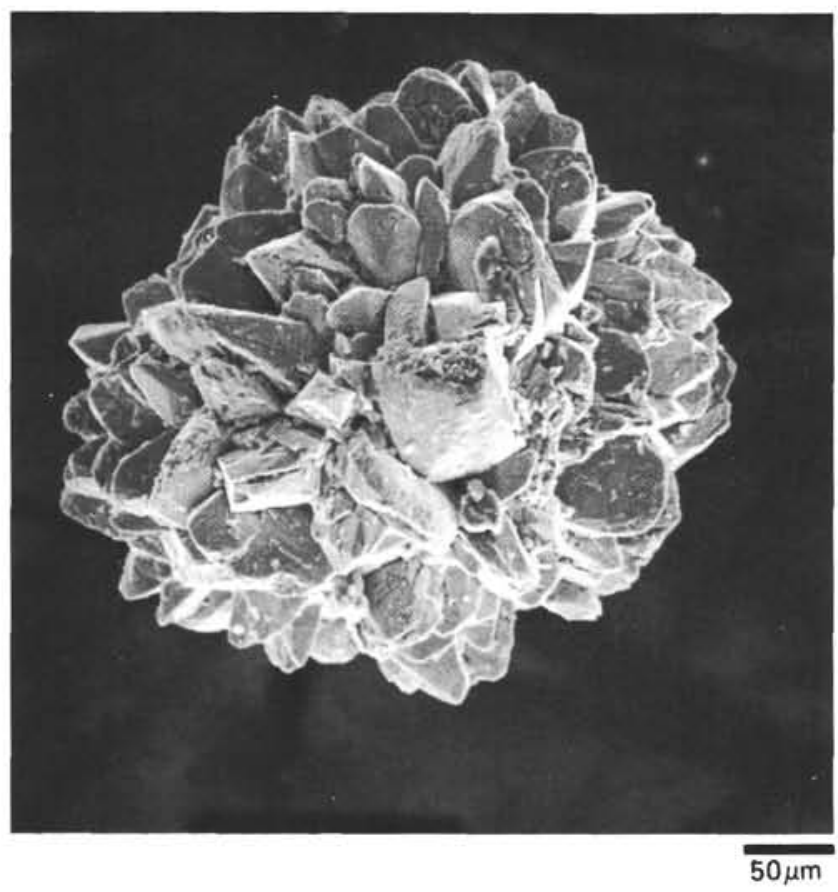

Figure 13. Radiating cluster of marcasite. Section 364 38-2.

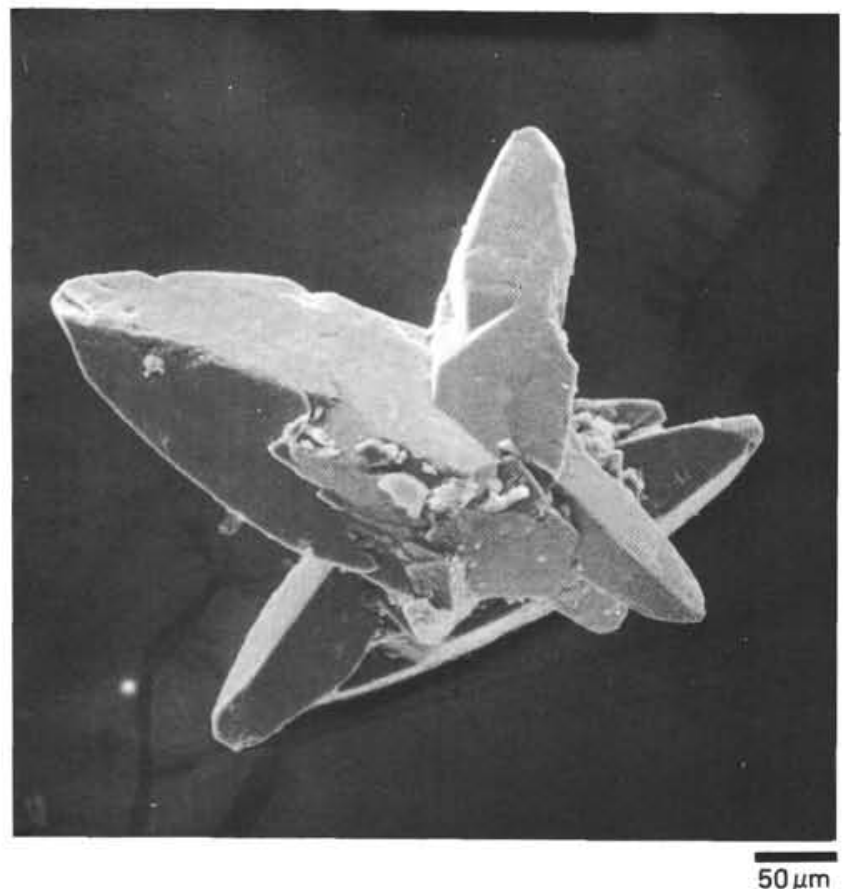

Figure 14. Pyramidal forms of marcasite. Section 364 23-1.

calcium. With calcium and sulfate in solution, gypsum precipitated once its solubility product was exceeded. The large size of the gypsum crystals (Figures 16 and 17) implies slow growth of the crystals within the sediment

Marcasite was found only off Angola at Sites 364 and 365 (Table 2). Pyrite and marcasite both form under

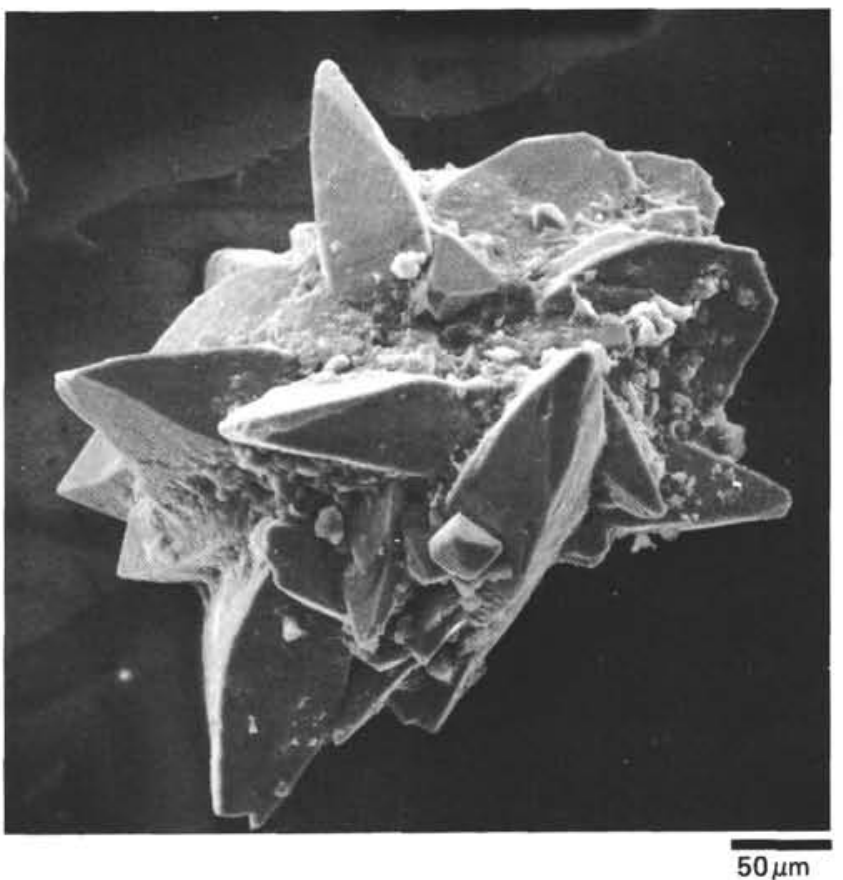

Figure 15. Pyramidal cluster of marcasite. Section 364-231.

reducing conditions by the activity of anaerobic bacteria (Edwards and Baker, 1951). Pyrite can form in alkaline, neutral, or weakly acidic environments, but marcasite forms under acidic conditions (Kraus et al., 1959). Marcasite is best known in association with brown coal, suggesting that the acidic environments of peat swamps are most suitable for marcasite crystallization. Peat swamps may have a $\mathrm{pH}$ on the order of 2.1 to 5.5 (Pettijohn, 1957) and brown-coal waters a $p \mathrm{H}$ on the order of 5.5 to 6.5 (Edwards and Baker, 1951). Such low $p \mathrm{H}$ values are an unusual feature of marine sediments. Moreover, Edwards and Baker (1951) believe that marcasite forms syngenetically only in freshwater environments and not in marine environments. They believe that its presence in rocks formed under marine conditions indicates post-depositional acidification. Nevertheless, a low interstitial-water $p \mathrm{H}$ value of 6.5 was recorded off Angola at Site 364. This very low $\mathrm{pH}$ together with the presence of marcasite seem more than coincidental, especially since both occur only off Angola. Furthermore, the $p \mathrm{H}$ values at Site 364 change erratically at close intervals down the hole-e.g., from 7.4 at about 470 meters depth to 6.5 at 530 meters, then back to 7.6 at 580 meters. These irregular fluctuations from alkaline to acidic and back again probably account for the sporadic, rather than consistent, presence of marcasite in the hole. Sapropelic shales, the marine analog of peat swamps, are also common in the Cretaceous cores where marcasite occurs, again suggestive of favorable environmental conditions for marcasite formation. Why marcasite is not found in the Cretaceous sapropelic facies at Site 361 is not known, but the fact that the $p \mathrm{H}$ never goes below 7.2 at Site 361 may be significant. 
TABLE 2

Electron Microprobe Analyses (in \%) of Selected Pyrite and Marcasite Grains

\begin{tabular}{llllllllllllrr}
\hline $\begin{array}{c}\text { Sample } \\
\text { (Interval in cm) }\end{array}$ & Class & $\mathrm{K}$ & $\mathrm{Si}$ & $\mathrm{Ca}$ & $\mathrm{Al}$ & $\mathrm{Ti}$ & $\mathrm{Mg}$ & $\mathrm{Fe}$ & $\mathrm{Mn}$ & $\mathrm{S}$ & $\mathrm{Cu}$ & $\mathrm{As}$ & $\mathrm{Total}(\%)$ \\
\hline $360-9-6,81-82$ & Botry. & 0.00 & 0.00 & 0.06 & 0.02 & 0.02 & 0.02 & 47.21 & 0.01 & 52.63 & $\mathrm{~N}$ & $\mathrm{~N}$ & 99.97 \\
$360-11-6,17-18$ & Mass & 0.00 & 0.00 & 0.04 & 0.00 & 0.02 & 0.03 & 45.59 & 0.02 & 52.12 & $\mathrm{~N}$ & $\mathrm{~N}$ & 97.82 \\
$361-5-5,16-17$ & Tube & 0.03 & 0.08 & 0.02 & 0.03 & 0.03 & 0.03 & 45.59 & 0.02 & 52.10 & $\mathrm{~N}$ & $\mathrm{~N}$ & 97.93 \\
$361-5-5,16-17$ & Framb & 0.01 & 0.03 & 0.10 & 0.02 & 0.02 & 0.03 & 46.04 & 0.02 & 51.23 & $\mathrm{~N}$ & $\mathrm{~N}$ & 97.49 \\
$361-27-4,62-63$ & Cube & 0.00 & 0.00 & 0.00 & 0.01 & 0.00 & 0.01 & 48.11 & 0.04 & 53.19 & $\mathrm{~N}$ & $\mathrm{~N}$ & 101.36 \\
$361-27, \mathrm{CC}$ & Mass & 0.08 & 0.42 & 0.14 & 0.31 & 0.03 & 0.07 & 46.33 & 0.01 & 52.50 & $\mathrm{~N}$ & $\mathrm{~N}$ & 99.87 \\
$362 \mathrm{~A}-2-3,60-62$ & Tube & 0.01 & 0.00 & 0.05 & 0.02 & 0.03 & 0.01 & 45.41 & 0.01 & 50.17 & $\mathrm{~N}$ & $\mathrm{~N}$ & 95.70 \\
$362 \mathrm{~A}-2-6,20-21$ & Mass & 0.00 & 0.00 & 0.02 & 0.00 & 0.00 & 0.03 & 46.15 & 0.03 & 51.47 & $\mathrm{~N}$ & $\mathrm{~N}$ & 97.70 \\
$363-26-2,94-96$ & Cube & 0.00 & 0.00 & 0.02 & 0.02 & 0.02 & 0.02 & 45.88 & 0.00 & 52.12 & $\mathrm{~N}$ & $\mathrm{~N}$ & 98.08 \\
$364-2-3,133-135$ & Tube & 0.02 & 0.01 & 0.03 & 0.02 & 0.00 & 0.02 & 45.10 & 0.67 & 53.08 & $\mathrm{~N}$ & $\mathrm{~N}$ & 98.94 \\
$364-21-4$, & Mass & 0.00 & 0.01 & 0.00 & 0.02 & 0.00 & 0.03 & 47.42 & 0.00 & 53.23 & $\mathrm{~N}$ & $\mathrm{~N}$ & 101.02 \\
$118-120$ & & & & & & & & & & & & \\
$364-22, \mathrm{CC}$ & Mass & 0.00 & 0.00 & 0.00 & 0.02 & 0.02 & 0.02 & 47.35 & 0.02 & 52.69 & $\mathrm{~N}$ & $\mathrm{~N}$ & 101.11 \\
$364-23-1,57-59$ & Pyram. & 0.00 & 0.00 & 0.00 & 0.04 & 0.00 & 0.03 & 44.60 & 1.41 & 52.11 & $\mathrm{~N}$ & $\mathrm{~N}$ & 98.19 \\
$364-24, \mathrm{CC}$ & Botry. & 0.00 & 0.00 & 0.03 & 0.02 & 0.03 & 0.02 & 47.03 & 0.12 & 52.39 & $\mathrm{~N}$ & $\mathrm{~N}$ & 99.64 \\
$364-38-2$ & Cluster & 0.00 & 0.00 & 0.08 & 0.01 & 0.02 & 0.02 & 44.62 & 0.63 & 52.43 & $\mathrm{~N}$ & $\mathrm{~N}$ & 97.80 \\
$364-38, \mathrm{CC}$ & Tube & 0.00 & 0.04 & 0.03 & 0.00 & 0.00 & 0.02 & 46.31 & 0.30 & 53.78 & $\mathrm{~N}$ & $\mathrm{~N}$ & 100.48 \\
$364-42-5,26-28$ & Mass & 0.00 & 0.00 & 0.03 & 0.02 & 0.04 & 0.02 & 45.98 & 0.00 & 53.38 & $\mathrm{~N}$ & $\mathrm{~N}$ & 99.47 \\
$365-2, \mathrm{CC}$ & Pyram. & 0.00 & 0.02 & 0.03 & 0.03 & 0.02 & 0.02 & 45.95 & 1.22 & 53.70 & $\mathrm{~N}$ & $\mathrm{~N}$ & 100.98 \\
$365-3-2,67-69$ & Mass & 0.02 & 0.00 & 0.03 & 0.00 & 0.00 & 0.01 & 44.60 & 0.24 & 53.08 & $\mathrm{~N}$ & $\mathrm{~N}$ & 97.98 \\
\hline
\end{tabular}

Note: $\mathrm{N}=$ Below detection limits. Standards: Troilite, Kakanui hornblende, Kakanui pyrope, No standards available for Cu and As.

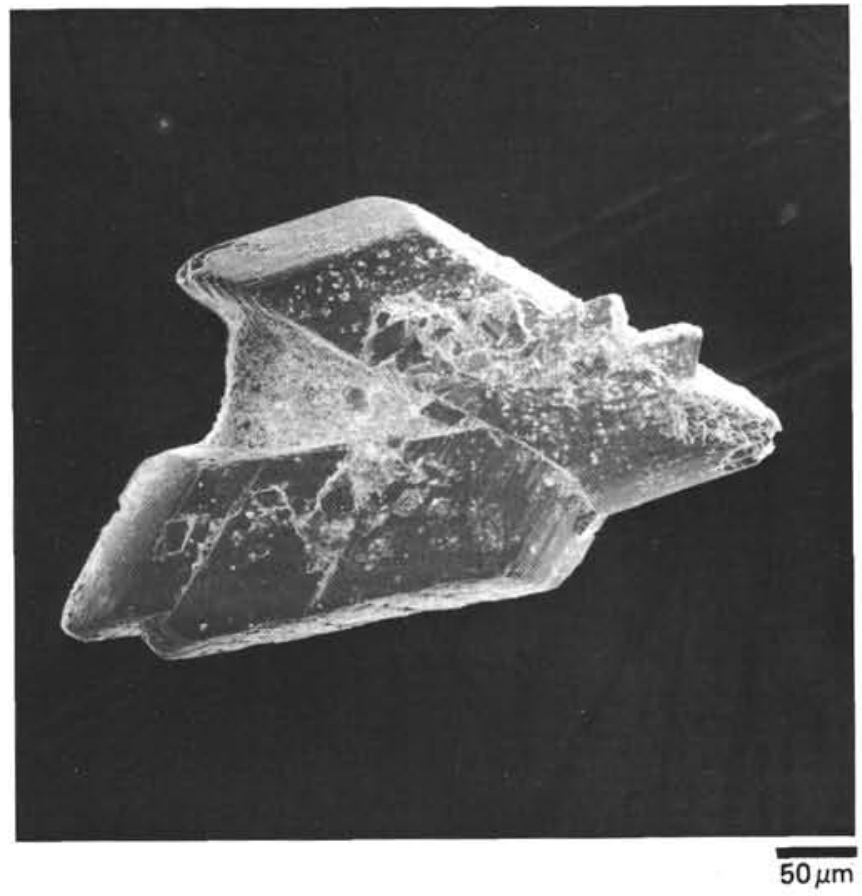

Figure 16. Gypsum (selenite) prisms forming interpenetration twins.

\section{CONCLUSIONS}

Iron sulfides of both pyrite and marcasite are abundant and assume a variety of morphological forms in Leg 40 sediments. Pyrite is common at all Leg 40 sites, but marcasite-which is rare in DSDP cores -occurs only at the sites off Angola(364 and 365). Both pyrite and marcasite form in reducing environments, but marcasite requires acidic conditions whereas pyrite

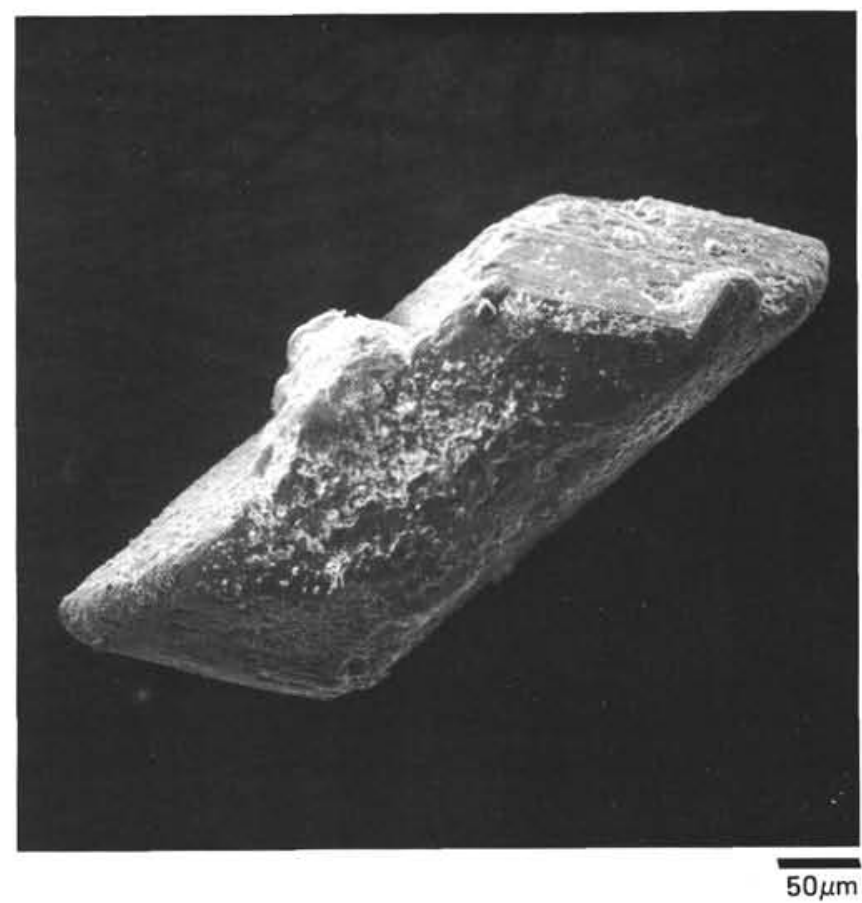

Figure 17. Gypsum (selenite) prism.

normally forms under more neutral or alkaline conditions. Only at Site 364 was the $p \mathrm{H}$ of interstitial waters low enough to approximate the peat-swamp acidity necessary for marcasite formation. These marcasite crystals also differ slightly from pyrite in their chemistry; marcasite contains more manganese (average $1.1 \%$ versus $0.1 \%$ ) and probably slightly less iron than pyrite.

An interesting association of gypsum and pyrite also occurs in some cores. Their association implies 
formation in a localized reducing (pyrite-forming) environment, with a $p \mathrm{H}$ at least temporarily low enough to dissolve some planktonic calcareous organisms. The derived calcium combined with already present sulfate ions to form gypsum once the solubility product of that mineral was exceeded.

\section{ACKNOWLEDGMENTS}

This study forms part of the work of the joint Geological Survey/University of Cape Town Marine Geoscience Unit. Both organizations are thanked for their support. Mr. R.H.M. Cross took the electron photomicrographs and $\mathrm{Mr}$. R.S. Rickard operated the microprobe. Dr. Victor Gostin kindly read a draft of the manuscript.

A special work of thanks is due to Dr. Brian McKnight, who first recognized marcasite in the shipboard samples. The writer is presently a member of the C.S.I.R. National Research Institute for Oceanology.

\section{REFERENCES}

Berner, R.A., 1964. Stability fields of iron minerals in anaerobic marine sediments: J. Geol., v. 72, p. 826-834.
1969. The synthesis of framboidal pyrite: Econ. Geol., v. 64, p. 383-384.

1970. Sedimentary pyrite formation: A.J. Sci., v. 268 , p. $1-23$

Carroll, D., 1958. Role of clay in the transportation of iron: Geochim. Cosmochim. Acta., v. 14, p. 1-17.

Criddle, A.J., 1974. A preliminary description of microcrystalline pyrite from the nannoplankton ooze at Site 251, Southwest Indian Ocean. In Luyendyk, B.P., Davies, T.A., et al., Initial Reports of the Deep Sea Drilling Project, Volume 26: Washington (U.S. Government Printing Office), p. 603-607.

Edwards, A.B. and Baker, G., 1951. Some occurrences of supergene iron sulphides in relation to their environments of deposition: J. Sediment. Petrol., v. 21, p. 34-46.

Kraus, E.H., Hunt, W.F., and Ramsdell, L.S., 1959. Mineralogy: New York (McGraw-Hill), p. 686.

Love, L.G. and Amstutz, G.C., 1966. Review of microscopic pyrite: Fortschr. Mineral., v. 43, p. 273-309.

Pettijohn, F.J., 1957. Sedimentary rocks: New York (Harper \& Brothers), p. 718.

Siesser, W.G. and Rogers, J., 1976. Authigenic pyrite and gypsum in South West African continental-slope sediments: Sedimentology, v. 23, p. 567-577. 